\title{
Social enterprise policy design: constructing social enterprise in the UK and Korea ${ }^{1}$
}

\author{
Chisung Park*, Mark Wilding ${ }^{* *}$ \\ ${ }^{*}$ Chung-Ang University, Seoul, Korea \\ ** Catholic University of Korea
}

Running title: Social enterprise policy design

Key words: comparative social policy, policy design, social construction, social enterprise, third sector, South Korea, United Kingdom

Accepted for publication 11 August 2012

Corresponding author:

Mark Wilding

Catholic University of Korea

43-1 Yeokgok 2-Dong

Wonmi-Gu, Bucheon, Gyeongi-Do, Korea;

Tel: 822-2164-6502

Fax: 822-2164-4785

E-mail: markawilding@hotmail.com

\footnotetext{
${ }^{1}$ This is an Accepted Manuscript of an article accepted for publication by Wiley in the International Journal of Social Welfare. The latest version is available online at https://doi.org/10.1111/j.14682397.2012.00900.x
} 


\begin{abstract}
Taking the elusive definition of social enterprise as its starting point, this study seeks to understand the impact of government policies in shaping social enterprises in the national contexts of the UK and South Korea. The social construction of target populations is utilised as a theoretical framework in order to identify which factors influence government policy. The research questions are addressed through a comparison of the two countries over a fourteen year period from 1997 to 2010. Despite very different contexts, governments in both countries have taken an instrumental approach to social enterprise. This tendency is more pronounced in Korea however, where government has limited the input of stakeholders and used an approval system to control access to the social enterprise name. The study concludes by recommending a more value-oriented approach to social enterprise.
\end{abstract}

\title{
Introduction
}

For over a decade, studies have been conducted with the goal of defining social enterprise, both in terms of a general meaning (Defourny, 2001; Ridley-Duff, 2007) and state-specific meanings (J. W. Kim, 2009; Pharoah, Scott \& Fisher, 2004). Still, despite extensive research there is no widely agreed upon definition. Instead, the characteristics of social enterprises have been shaped by the activities of social enterprise practitioners and/or government policies (Parkinson \& Howorth, 2008; Teasdale, 2011). The present study is concerned with the way in which governments attempt to mould the identity of social enterprises through policy design. Policy design is usually the outcome of the decisions of many different people, and has been defined as 'the elements found in the content of policy that affect target populations and other citizens' (Ingram \& Schneider, 1993, p. 71). Among various policy theories used to describe policy design 
processes (e.g. Sabatier, 2007), this study adopted the social construction of target populations because its emphasis on the constructed nature of policy means that it is suited to exploring relations between contexts, policy changes and social constructions (Ingram, Schneider \& deLeon, 2007; Schneider \& Ingram, 1993, 2005; Schneider \& Sidney, 2009). Specifically, this study compared two cases - the UK at the level of the Westminster government, and South Korea (hereafter Korea) - to explore whether government policies or any other factors in the respective countries drove social enterprise towards similar (or different) paths.

This study asked, first, 'What were the contextual factors behind the introduction of social enterprise policies and how did they influence government perspectives of social enterprise?' In order to answer this question, various contexts of the countries, such as the socioeconomic situation and the role of policy entrepreneurs, were explored, as proposed in the social construction of target populations literature. The second question is directly connected with government policy design efforts; 'What is the impact of government on the social construction of social enterprise?' This question is concerned with the ways in which government actions and intentions influence the social construction of social enterprise. The social construction of target populations provides a framework to analyse the impact of the intentions of policy makers, the extent of control by the government, and citizen participation. On the basis of the findings of the first two questions, the third question was 'Do these factors result in similar (or different) social constructions of social enterprise, and why?'

There is interest in using social construction and government framing to understand the development of social enterprises (Grant \& Dart, 2008; Mawson, 2010; Parkinson \& Howorth, 2008; Teasdale, 2011). Studies have focused on issues ranging from identity and self-definition as social enterprise (Grant \& Dart, 2008), to implementation problems and lack of support for 
regional networks (Mawson, 2010). Social enterprise discourse in the UK was examined by Teasdale (2011) who found that the social enterprise construct had become progressively wider as a consequence of efforts by both social enterprise practitioners and government. Parkinson and Howorth (2008) revealed how the language of social entrepreneurs in the UK differed from that of the government. They found that social entrepreneurs drew legitimacy from local or social morality, in contrast to the government generated rhetoric of enterprise with its emphasis on management, efficiency and financial independence (Parkinson \& Howorth, 2008). While these studies have contributed significantly to understanding the construction of social enterprise in the UK, they tell us less about how social constructions impact upon policy design. The social construction of target populations in particular is suited to uncovering government motives and the ways in which social constructions of various groups in society impact upon policy design. As such, the social construction of target populations is useful for understanding differences between governments and taking a comparative approach.

The present study was not the first to compare the UK and Korea. McCabe and Hahn's (2006) explorative comparison identified some similarities and differences between the countries. They found substantial surface-level differences between social enterprise in the two countries, that is, Korea was focused on welfare-to-work policies while the UK had a wider social economy. However, they also found some similarities, which at the time included the comparatively marginal role of social enterprise, the focus on health, social welfare and environmental services operating between state and market, and the burden of expectation in terms of addressing social and economic problems in both countries (McCabe \& Hahn, 2006). Given the reported move of social enterprise in the UK from the economic periphery to the centre (Haugh \& Kitson, 2007), and the significant growth of social enterprises in Korea in recent years (ML, 2009), the present 
study re-evaluated social enterprise in the two countries according to the social construction of target populations.

\section{The social construction of target populations approach to policy design}

The social construction of target populations is the theory that the intended benefits and burdens of policy result not only from the political resources of various groups in society, but are also a response to the social constructions of the groups themselves (Ingram et al., 2007; Schneider \& Ingram, 1993, 2005; Schneider \& Sidney, 2009). Over the years, a very broad range of factors which could impact upon social constructions have been identified. For example, Schneider and Ingram (2005) referred to such factors as diverse as social movements, social science and demographic changes. We have summarised the social construction of target populations according to direct factors, indirect factors and design intention.

Indirect factors include external events, political and economic context, and policy feedback. The term 'external events' refers to incidents which are outside the control of national governments that lead to new social constructions and may in turn be embedded by public policy. Schneider \& Ingram (2005) gave the example of the racial profiling of people from the Middle East or of Arabic descent after the September 11 attacks. More generally, the political and economic context is important, because social constructions are often influenced by earlier policy and political choices (Schneider \& Ingram, 1993), and 'once a course has been set in a positive direction in relation to the construction of some group or idea, the difficulties of change accumulate over time' (Schneider \& Ingram, 2005, p. 6). A related concept which in reality can be very difficult to separate is policy feedback - the interplay between the top-down and bottomup aspects of the policy process. Drawing on Wildavsky (1979), Schneider and Ingram (2005) 
argued that structural opportunities for social mobilisation and changes in social constructions could occur as a result of previous policies. It is in this feedback loop that we can see the reciprocal way in which public policy and social constructions impact upon each other. Moreover, this reciprocal relationship highlights the complexity of the policy design process. As Wildavsky (1979, p. 4) stated: 'past solutions, if they are large enough, turn into future problems'.

Direct factors include public policy and (policy) entrepreneurship. Public policy is government's main mechanism to 'anchor, legitimize, or change social constructions' (Schneider \& Ingram, 2005, p. 5). Especially important in the present study is whether policy leaders wield a significant influence in shaping the benefits and burdens of social enterprise policy, and whether this is connected with the social construction of the target population (i.e. social enterprise). Research has highlighted how 'the causal link between social constructions and policy designs is not inevitable' (Nicholson-Crotty \& Meier, 2005, p. 223), and Schneider and Ingram therefore recognised economic, political, social and moral entrepreneurs as facilitating consensus formation between disparate groups (Schneider \& Ingram, 2005). Indeed, the role of entrepreneurship as a catalyst is well documented in research on the policy process (Kingdon, 1995; Mintrom \& Norman, 2009). Entrepreneurs can therefore be seen to play an important role in translating social constructions into policies.

It is also important to consider design intention, as this can reduce or strengthen the resources of the target population (Schneider \& Ingram, 1997). We use the term 'design intention' not only to refer to the intended distribution of benefits and burdens, but also more specifically to refer to whether benefits and burdens are intended as goals in themselves or as a means of achieving other goals. If a policy is designed to benefit the target population as a goal 
in itself, the target population may have more chances to increase its autonomy (Chikoto, 2007). In this way, government may choose to use social enterprise as a direct path to serving social needs or achieving other underlying values inherent in social enterprise (i.e., cooperation and mutual support), regardless of other policy goals, such as efficient provision of services. This is the value-oriented approach. On the other hand, if government attempts to utilise the target population as a means to achieve another policy goal, the government may want to exercise more control. In this sense, social enterprise would be utilised only because it is a relatively efficient instrument to achieve another mission (i.e., economic targets such as relieving unemployment). For the purposes of this study we will refer to this type of rationality as the instrument-oriented approach.

\section{Research design}

This study took an explorative format utilising a small-N design (Yin, 2002) under the theoretical framework of social construction of target populations. Comparisons were made according to the factors discussed in the theoretical section - indirect and direct factors as well as design intention, in order to compare their impact on the social construction of social enterprise in the UK and Korea.

The UK and Korea were selected as cases for comparison as they are amongst a relatively small group of nations which have legislated for social enterprise. Still, they are very different countries, as seen by the parliamentary system of government in the UK in contrast to the presidential system of Korea, and the long history of democracy and civil society in the UK, while Korea began to democratise after the end of military dictatorship in the late 1980s (McCabe \& Hahn, 2006). While the UK is among the oldest welfare states, and the state has a tradition of directly providing a wide range of health and welfare services from large scale social 
housing to social services and hospitals, the Korean government has traditionally been a low social spender (Hwang, 2006). There has been an increase however in the range of services available, particularly following the introduction of the National Basic Livelihood Security System in 2000. Yet, due to the continued weight given to economic development by the Korean state, this has also been viewed as an opportunity to create new jobs and stimulate the economy (Peng, 2009). Interestingly, both countries are now focused on increasing non-state provision, although they have approached this from different directions, in the UK there has been a shift in emphasis from the state as provider to purchaser, while the Korean state continues in its role as regulator, albeit with increased social spending (Kendall, 2000, Peng, 2009).

There may also be some similarities between the countries, as it has been claimed that Korea benchmarked the UK system of social enterprise when formulating policy around the period 2004-2006 (Joongang Sunday, 2008). Also in a general sense, the public sector reforms of managerialism and outsourcing within the context of hierarchical governance, introduced in Korea in the 1990s, echo those introduced in the UK from the 1980s onwards (An, Halligan \& Wilks, 2002). Accordingly, in both countries, the impact of social enterprise has been relatively high on the public sector (Carmel \& Harlock 2008, Park, 2008). Yet, there are usually seen to be more differences than similarities between the countries. As such we approach the case study from a most different perspective in order to answer the research questions and examine whether the different contexts lead to similar or different social constructions and policy usages.

\section{Case analysis of social enterprise in the UK and Korea}

In both the UK and Korea, the term 'social enterprise' has only come to be widely used during the past decade. This time has seen tremendous developments however, with social enterprise 
policy in the two countries being shaped by direct and indirect factors, as well as design intention. Since it is almost impossible to exclusively separate the influences of these factors we will examine developments chronologically. From a government perspective it appears that interest in social enterprise started earlier in the UK than in Korea. As such the time frame begins two years earlier in the UK (1997) than Korea (1999). We broke the time period into three separate phases to aid both ease of comprehension and comparison.

\section{Period one: the incubation period}

$\underline{\mathrm{UK}}$. While the late 1990s were a time of relative economic stability in the UK, the political ground was shifting. The election of a Labour government in 1997 after 18 years in opposition meant that the 'third way' project and its 'post-ideological approach' moved centre stage. A consequence was that social exclusion and community development were high on the agenda, as was competitive tendering for public services, an area in which the government was interested in capacity building (Kendall, 2000). As highlighted in Table 1, social enterprises were beginning to emerge in several sectors, even if the term 'social enterprise' itself was new to many. The day after he became prime minister in May 1997, Tony Blair described his aim of 'backing the thousands of social entrepreneurs. Those people who bring to social problems the same enterprise and imagination business entrepreneurs bring to wealth creation' (Smith, 2000, p. ?). The new Labour leadership clearly saw the potential for social enterprise, particularly in relation to social exclusion (HM Treasury, 1999). However, no explicit policies were made regarding social enterprise at this time.

Table 1 to feature here 
This did not deter social enterprises from trying to gain more support, both from local and central government. In 1998 Social Enterprise London (SEL) was set up by social enterprises, with financial support from London councils and state funding agencies to support the development of social enterprises in London. It is important to note the central role of cooperatives at this time, as the initial subscribers of SEL all belonged to the cooperative movement (Teasdale, 2011). This was followed by the establishment of a national body in 2000, the Social Enterprise Coalition (SEC), which was formed in order to secure more government support, particularly as the members thought that social enterprise provided a practical response to three of the government's policy drivers; competitiveness, social inclusion and a modernising agenda (Social Enterprise London, 2000). In this sense, the policies of the third way created an environment in which social enterprises were encouraged to push for further government support, completing a feedback loop.

Korea. The Korean welfare system traditionally placed more emphasis upon the family and employer rather than the state. However, due to an external event, the 1997 Asian financial crisis, this traditional welfare system was threatened. A large number of businesses underwent structural reform at the behest of the IMF, and many people lost their jobs and were therefore unable to support their families. As highlighted in Table 2, in the face of these urgent problems the Korean government introduced the 'Public Work Programme' as part of the National Basic Livelihood Security Act in 1999. The main goals of this policy were to resolve welfare and unemployment problems simultaneously by providing social security and creating jobs for the poor unemployed (Park, 2009). Thus, the Ministry of Health and Welfare (MHW) was a key policy actor and, in order to accomplish the policy goal, the MHW engaged the pre-existing local 
community institution, 'Self Support Community Centres' (SSCCs) as a policy partner, providing services under contract to the MHW.

\section{Table 2 to feature here}

SSCCs originate from the mid-1970s when volunteers began to organise at the local level for the purpose of helping the poorest people, especially through job training or providing temporary (often menial) jobs. There are similarities between the SSCCs and work integration social enterprises (WISEs), as they share many of the characteristics of social enterprise as identified by Defourny (2001). For example, SSCCs follow rules such as a minimum amount of paid work, an explicit aim to benefit the community, an initiative launched by a group of citizens, and a decision-making power not based on capital ownership. Thus, social enterprise in Korea can be traced back to the SSCCs (Kim, 2008). The government's aim in partnership with the SSCCs was to benefit the low-income level by connecting job provision and welfare services. However, the focal point was not the mid-to long-term provision of welfare services, but to enable low-income welfare recipients to become self-sufficient in the short-term in the market. The government needed to reconsider the policy though when the programme struggled to meet these aims.

\section{Period two: development of social enterprise policies}

$\underline{\mathrm{UK}}$. Under the second Blair government support for social enterprise increased considerably. The Social Enterprise Unit was launched inside the Department of Trade and Industry (DTI) in 2001 with a coordination and development remit. While there were policy entrepreneurs in the form of social enterprise practitioners who lobbied the government, there were also policy entrepreneurs inside government, including not only Blair and Brown but also other senior ministers such as John Prescott and Patricia Hewitt (Lyons, 2002). As Secretary of State at the 
DTI, Hewitt oversaw the introduction of the Social Enterprise Unit and the subsequent social enterprise strategy in 2002. The strategy was a three year plan concerned with promoting and sustaining social enterprise. Notably, the main strategy document set out the government definition of social enterprise as 'a business with primarily social objectives whose surpluses are principally reinvested for that purpose in the business or the community' (DTI, 2002, p. 14). The definition was formulated in agreement with a selection of social enterprise practitioners (Bland, 2010), and also included a list of characteristics that the DTI believed successful social enterprises exhibit. Along with entrepreneurial and social aspects, these included 'stakeholder engagement' and 'democratic and participative management' (DTI, 2002, p. 16). Nevertheless, the characteristics were interpreted as a move towards including social businesses (i.e., profitdriven businesses with social goals), which were seen as having a role to play in public service reform (Teasdale, 2011). This expansion of the social enterprise concept was resisted by cooperatives and community-based social enterprises due to the belief that social goals are at the core of social enterprise (Teasdale, 2011).

The new policy was accompanied by new funding patterns, intended to build the capacity of the third sector, which through quangos such as Futurebuilders, offered loans and grants to third sector organisations delivering public services (Alcock, 2010). It has been suggested that government strategies at this time represented the normalisation of voluntary and community organisations, including social enterprises, as market-responsive service providers disconnected from their original social goals (Carmel \& Harlock, 2008). Similarly, in the area of work integration, Aiken and Bode (2009) found that managerialist partnership structures led to the use of social enterprise and other third sector organisations as deliverers of welfare programmes. Significantly they found that the need of the organisations to focus on work integration prevents 
them from being fully economically independent and leaves them dependent on state funding. In addition, they argued that a focus on contracts 'threatens to denude by neglect the milieu - the infrastructure, the lattice of networks, trust and relationships which had been created and reproduced over many years and within which social empowerment and work integration activities reside' (Aiken \& Bode, 2009, p. 221).

While the government had not been entirely responsible for the social construction of social enterprise, developments do suggest that the government attempted to use social enterprise in an instrumental manner in order to provide services. In creating this version of social enterprise, the government relied upon two extant social constructions; entrepreneurs and voluntary sector organisations. New Labour's view of entrepreneurs as deserving of policy support can be seen in party documents (Labour Party, 1996), and the way in which the Labour governments sought to expand entrepreneurialism to new areas including social policy (Scourfield, 2007). There was also an attempt on the part of government to associate social enterprise with the positively constructed voluntary sector. The voluntary sector was integral to the new Labour brand, as seen by the emphasis on the third sector and the inclusion of voluntary organisations in the revised party constitution which was intended to make the party more electable (Labour Party, 1996). While the party had long lasting links with the sector it is worth noting that public awareness of the voluntary sector in the late 1990s was boosted by the National Lottery TV show, which for the first few years had huge viewing figures, and which contained information about the voluntary sector when it told viewers where the proceeds of the lottery were spent (Kendall, 2000). As such, it did not trouble the Labour Party to offer benefits to the positively constructed voluntary sector. 
Social enterprises were now receiving policy support and funding, and in 2005 the government established the community interest company (CIC) legal form, specifically for social enterprises. The legislation contained an asset lock mechanism (also offered by industrial and provident societies) to restrict the proportion of profit which can be redistributed to shareholders to 35 per cent. More divisively, the CIC regulations did not stipulate the democratic structure of social enterprise. This meant that there was no legal requirement to involve stakeholders in decision making processes, unlike in other European countries (Nyssens, 2009). The CIC regulations therefore represented a significant shift from the government's earlier view of the characteristics of successful social enterprises. Some have argued that the governments' approach overlooked the employee-owned or cooperative sectors (Ridley-Duff, 2007). Others have suggested that the CIC form is a move away from the third sector and an attempt to give social enterprises more freedom to act like mainstream businesses (Dunn \& Riley, 2004). This perspective is supported by the light touch role of the CIC regulator (Nicholls, 2009). While the widening of the social enterprise construct to include social businesses in this way may allow for the effective delivery of services, it again suggests an instrumental view of social enterprises from the government.

Korea. With the shift in concern from the Asian financial crisis (welfare and unemployment) to jobless growth (unemployment only), the focus of the government was modified to 'longterm job creation rather than social service provision for the socially disadvantaged' (Park, 2009, p. 19). Consequently, a new social enterprise program was started in the Ministry of Labour (ML), which signified a refocusing of the government strategy from a mixture of welfare and labour policy to just labour policy (Park, 2008). Rather than the SSCCs, the primary policy partners in 
the ML's 'Social Workplace Programme' (SWP) were closer to the US-style of social enterprise; nonprofits with an emphasis on revenue generation in the market economy. The SWP, which was implemented mostly by local branches of the ML and its contractors (Ko, 2007) also led to the expansion of target beneficiaries of the policy from the vulnerable to the general unemployed, through the introduction of a job stabilisation policy (Ko, 2007). Nevertheless, the majority of jobs created were unstable and temporary (Kim, 2008; J. W. Kim, 2009; Ko, 2007; Park, 2008). Searching for an alternative to overcome these problems, the ML consulted academics and NGO professionals before modifying the policy from the SWP to the Social Enterprise Policy.

The programme introduced by the Social Enterprise Promotion Act (SEPA) in 2007 can be seen as a modification of the SWP because the focus remained on secure job creation (Park, 2009). Indeed, between periods 2 and 3, not only was their continuity in the unemployment problem (i.e., jobless growth), but the main policy actor was the same (ML), and the policy field and target beneficiaries were the same. Only the policy tool changed, from contracting out to the approval system. The approval system is so named as, under Article 19 of the SEPA, the use of 'social enterprise or similar terms' is prohibited without approval from the ML. With the SEPA the main intention of the government was to utilise social enterprise as an instrument to achieve job stabilisation. This instrumental rationality of the government can be demonstrated both through the redefinition of social enterprise and the use of the approval system as a means of control.

Social enterprise was redefined as a market-oriented institution due to its ability to (relatively cheaply) help resolve the jobs crisis. The internal memoranda of the SWP Task Force in 2005 reveal how government officials argued for the programme to be more 'market-oriented' and for 'sustainable profit-oriented' organisations, thus underlining their desire for the 
participation of business firms (Park, 2008, p. 10). In addition, they argued that the 'marketfriendly American model is better than the European one' and saw job creation as the social role of business firms (Park, 2008, p. 11). This market-oriented perspective served to restrict the meaning of social enterprise to a financially sustainable entity functioning in the market.

In the SEPA, the government categorised social enterprises into four organisational types - job creation type (WISEs), social service provision type, mixed type (a combination of the WISE/social service types), and the miscellaneous type. According to Article 8 of the Act, the purpose of the approval system is the prevention of inappropriate social enterprise emergence, or in other words, initiatives that do not correspond to the ML's criteria. In order to be approved as a social enterprise, an organisation must fulfil seven criteria relating to the type of organisation, the proportion of paid-employees, social goals, decision making governance, organisational rules, and limited profit-distribution. When an organisation meets these criteria it is also eligible to receive a range of support from the government, including financial subsidies (i.e. initial capital and salary support), managerial support, tax exemption, and social insurance support (ML, 2009). Academics have argued that social enterprise cannot be limited to a specific meaning, but instead requires a flexible and diverse definition (Defourny, 2001). In Korea, however, diverse types of social enterprise (i.e. nonprofits or SSCCs) are no longer considered to be social enterprises, even when their mission and operations fit with broad theoretical definitions. Organisations are subject to a very high degree of coercive isomorphism, as they must agree to follow government, not just to receive funding, but even to be considered social enterprises (Kim, 2010). The ban on using the name social enterprise without government approval indicates the high degree of governmental control, and demonstrates the legacy of the developmental state which was at its height in the 1970s when the government demanded that Korean multinationals 
operate in the nation's interests (Park, 2009). The approval system has had the effect of standardising the social enterprise sector. While this increases efficiency, it can also lead to a loss of flexibility, diversity, and most importantly autonomy for social enterprise. In this way, the resources of social enterprises have been reduced, and they have become more dependent upon government.

Period three: the refining of social constructions

$\underline{\mathrm{UK}}$. In the final period of this study the social constructions of social enterprise which were created in the second period were refined. The 2006 merger of the Social Enterprise Unit with the Active Communities Directorate to form the Office of the Third Sector, partly a result of the lobbying of voluntary sector organisations (Alcock, 2010), meant a move away from the DTI. Teasdale (2011) has documented how this move led to a widening of the social enterprise construct to include earned-income discourse, that is, voluntary sector organisations providing public services. Changes within government also appear to have encouraged an emphasis on earned income, as following the arrival of Patricia Hewitt as Health Secretary, the government further expanded the range of areas in which it was promoting social enterprise to include the National Health Service (NHS) (Department of Health, 2006). Significantly, an additional social enterprise unit was established within the Department of Health to support groups of employees who wanted to opt out of the NHS, marking a much more proactive approach from the government. Government figures estimated 62,000 social enterprises in the UK in 2009 (Hampson, 2009), a figure which is attributable to the widening of the social enterprise construct, and greater use of the organisations in providing public services. 
These developments raised concerns that social enterprise represented a new form of privatisation along with inferior wages and working conditions (Marks \& Hunter, 2007). Moreover there are concerns that the government's approach limited the potential of social enterprise to fulfil their goals. Some observers argued that social enterprises were beginning to display 'coercive isomorphism' under pressure from procurement policies and 'mimetic isomorphism' as they imitated best practices in order to survive (Aiken \& Slater, 2007). While it may be expected for government to contract with large organisations, the danger is that through isomorphism, some of the benefits of the market may be lost, as differences and hence choice between providers becomes less clear (Aiken \& Slater, 2007).

Korea. The defining characteristic of the third period in Korea was increasing focus on job creation. Table 3 shows that organisations whose mission is to create jobs have faced lower barriers to be awarded social enterprise status. Considering that the mixed type also emphasises job creation, the vast majority of social enterprises can be seen as focusing on job creation. In addition, in 2009, the ML reported that more than half of the total organisations (263 out of 515) that had applied for social enterprise status since 2007 had not been approved. It should be noted that the main reason for rejection was a lack of profit from business activities (108 out of 263 rejected organisations) (ML, 2009).

\section{Table 3 to feature here}

A further consequence of the approval system concerns the organisational background of social enterprises. Business firms dominate (209 organisations, 41.7\%), while 148 (29.6\%) are approved nonprofits (i.e., nonprofit organisations and social welfare foundations) and 130 
$(25.9 \%)$ are incorporated associations. Other organisational types are SSCCs (13 organisations, $2.6 \%$ ) and educational foundation (1 organisation, $0.2 \%$ ).

\section{Table 4 to feature here}

Following the election of President Lee Myung-Bak, social enterprise has remained on the political agenda (Office of the President, 2008). Perhaps unsurprisingly though, under Lee's conservative administration the emphasis has remained on a market-oriented approach; 'social enterprise should survive in the market' (ML, 2009).

However, attempting to situate WISEs in the market is problematic, not least because employees in WISEs, who include the elderly along with people with disabilities, are often unskilled labourers (S. K. Kim, 2009). Moreover, the market approach can detach the organisations from their social goals, as they strive instead to meet financial goals. Consequently, the majority of jobs created have been low quality, as they have been either temporary, required unskilled labour, or provided a low-income (J. K. Kim, 2009). Attempts to meet government targets can have a similar effect. For instance, when the ML took the initiative in policy making, the group of target beneficiaries expanded to the general unemployed (Ko, 2007). While the definition of social enterprise in Article 2 of the SEPA stresses that 'social enterprise seeks social goals by offering social services or jobs to the socially disadvantaged and the vulnerable' (emphasis added), in reality due to the need to meet government targets, Korean social enterprises take on a much more general role.

\section{Comparing the construction of social enterprise in the UK and Korea}

This case-study has highlighted the similarities and differences between the two countries as displayed in Figure 1 below, which compares the two countries according to indirect factors 
for social construction, the problem identified, direct factors for social construction, and design intention.

Firstly, the contrasting political and economic situations meant that indirect factors were different in the two countries, as were the problems identified. In the UK, a level of continuity with earlier policies in terms of outsourcing welfare services meant that it was imperative to build the capacity of providers, as the market had failed to meet the needs of the state. The policies of the third way also encouraged the development of social enterprises as, along with an emphasis on tackling social exclusion, they simultaneously stressed competitiveness and social goals. Later, when the process of outsourcing was extended to the NHS, the problem of finding service providers once more reared its head. On the other hand, in Korea, the Asian financial crisis as an external event, followed by jobless growth, meant that the government was seeking a means of creating jobs.Initially the target recipients were welfare recipients and the near poor, however when unemployment levels remained high despite economic growth, the government changed its focus from a combination of labour and welfare policy to concentrating on labour policy.

\section{Figure 1 to feature here}

Moving on to direct factors, in the first period the SEC was the main initiator in the UK, while the government at that time was less active, and thus practitioners were a direct factor in the initial social construction. Later, when the government introduced social enterprise policies, they revealed a view of social enterprise as a means to respond to market failure, and subsequently perceived state failure. Both of these changes in social construction were introduced despite a degree of resistance from social enterprise practitioners. In Korea the government was the main actor to introduce social enterprise. Unfortunately, it is difficult to find 
evidence of stakeholder involvement in the process of policy design in Korea. Since citizens were not familiar with the concept of 'social enterprise' and they did not possess sufficient information, there was little chance of their views being heard by policy makers in order to influence policy design processes. Thus, the government, policy advisors and senior bureaucrats were the dominant actors in the design of social enterprise policy in Korea. In the second period, professionals from civil society were invited to help design the policy, but their role was limited to assessing the potential usefulness of social enterprise in meeting the problem of jobless growth. Interestingly, despite different definitions and specific policy goals in the two countries, government intentions displayed instrumental rationality towards social enterprise, and the role of social enterprise as public service provider was stressed. The extent of instrumental rationality in the two countries differed however, largely due to the different combinations of actors which participated in the policy processes, but also because of different economic situations and government intentions. In Korea, the market-oriented policy approach has been accompanied by strong government control, as can be seen most clearly with the approval system, which has been used primarily in order to create organisations which can respond to the problems of jobless growth. This tendency has been less marked in the UK, where the government has been keen to promote social enterprise as a solution to a wider range of problems. In part, this is due to the state's history of involvement in a wider range of welfare services when compared to its Korean counterpart. Still, all things considered, the degree of control of the UK government over social enterprise was relatively limited. A key difference here can be seen in the way that the leaders of the UK government, while interested in public service reform, were also focused on the need to be seen to be delivering advantages to the voluntary sector, while the Korean government 
prioritised the need to be seen to be effectively responding to economic challenges at all costs, and thus reprised its role as the developmental state.

\section{Discussion and conclusion}

In both the UK and Korea governments have been very active in introducing social enterprise policies. Through the case analysis, this study found both similarities and differences between the policies of the UK and Korea. Taking similarities first, in both countries the initial rhetoric was concerned with social goals, yet the practice has been more concerned with meeting instrumental goals. These instrumental goals have differed according to the national welfare systems, with the UK government prioritising efficient service provision, while the Korean government used the approval system to focus on job creation, and changed the target beneficiaries from the vulnerable unemployed to the general unemployed. A consequence is that, in both countries, governments have limited the ability of social enterprise to respond to social problems. One explanation for this is due to a lack of integration in the means-ends hierarchy. It seems that both the UK and Korean governments have not always prioritised social enterprise as a means of pursuing value rationality amidst the tangled web of means and ends that sometimes characterises modern government (Simon, 1997).

This brings us back to the complexity of the policy process and Wildavsky's (1979) warning about past solutions leading to future problems. In the UK and Korea governments have utilised social enterprises as a solution to the lack of capacity amongst government contractors and as a means of job creation respectively. This has impacted on the autonomy of social enterprises, in that they have become more dependent upon the state through contracts and the approval system. The dangers of organisations operating in close proximity to the state are well 
documented (Wolch, 1990). In addition, it could jeopardise the existing ability of social enterprises to raise their own funds and to provide a real alternative to state or private sector provision.

Though the role of government differs in the two countries, it has nevertheless had a significant impact. The UK government was not the only actor, and social enterprise practitioners played an important role. Still, the role of the UK government as a policy entrepreneur was influential, particularly as leading ministers acknowledged the strategic importance of the voluntary sector (Hewitt, 2001). In addition, the Labour government in the UK provided considerable funding to the community and voluntary sector and promoted social enterprise in its efforts to create a mixed economy of welfare (Aiken, 2006). In this context, the role of policy entrepreneur has been important, as discussed in the literature on the policy window model (Kingdon, 1995), advocacy coalition framework (Sabatier \& Weible, 2007) or policy entrepreneurship model (Mintrom \& Norman, 2009). While successive Korean administrations have also supported the development of social enterprise, the legacy of the developmental state has been influential in the introduction of an approval system and the way in which government has controlled private organisations in order to be seen to be benefiting the public. One consequence of government in the UK not totally constructing the concept is that there are many more social enterprises in the UK and they take on a wider range of forms. Nevertheless, they face similar difficulties to their Korean counterparts in terms of achieving their social goals. It is understandable that social enterprise policy differs by nation as governments construct social enterprise policies according to national context. However, constructing an instrument-oriented social enterprise policy means that it is difficult for social enterprises to operate under less hierarchical models of governance. 
Making significant changes to the construction of social enterprises may be difficult however, due to the way in which social constructions can become embedded over time. This can be seen in the UK through the strengthening of the instrumental view of social enterprise under the Cameron government since the 2010 election. Increased use of social enterprises as public service providers is at the core of the flagship 'Big Society' policy programme. While there has been an attempt in the Public Service Act, passed in 2012, to make the creation of 'social value' an important procurement criterion, according to market liberal interpretations, all enterprises may be seen as creating social value (Teasdale, Alcock \& Smith, 2012). There is considerable room for interpretation by the commissioners of services, however in light of the public spending cuts it seems likely that social enterprises may be pitted against private companies in order to provide efficient services. The established social construction has also been maintained in Korea where the existing construction of social enterprise has already survived the transition to a new president and ruling party following the 2007 elections. Most significantly, the approval system is still in operation and the proportion of social enterprises that are classified as the job creation type has grown each year (see Table 3).

While other studies have examined the construction of social enterprise (Mawson, 2010; Parkinson \& Howorth, 2008; Teasdale, 2011), we have also illustrated how the social constructions of social enterprises have been important in their instrumental use by government in the UK, and particularly in Korea. This study has highlighted how governments have been able to make significant changes to social enterprise within a relatively short period of time. The theoretical framework of the social construction of target populations has been appropriate for a comparative examination of the use of social enterprise as a policy tool. A limitation of the framework though is that its applicability is limited to countries with social enterprise policies. 
Nevertheless, there are a growing number of countries in this category (Kerlin, 2010). The social construction of target populations therefore has potential as a comparative framework for the study of social enterprise.

Still, there are counter arguments, which may dispute what could be interpreted as a suspicious view of government. For instance those who take a more positivistic approach to the policy process, who argue that policy makers have few alternatives, particularly in the context of increased pressure to reduce government spending, may find our perspective to be too critical of government and policy makers. Moreover, it is unlikely that those who receive benefits from social enterprise policy, especially those organisations with the moral and financial backing of government will feel that there is bias in the policy process, although this is likely to change rapidly if they come to receive the burdens of policy.

Changing social constructions is not impossible however, and policy design is a continual process. In order to create a policy framework for social enterprise that enables them to follow a more value-oriented approach, there are steps which policy makers could take. Firstly, in the Korean case, the replacement of the approval system with a much lighter form of regulation would recognise the diverse kinds of social enterprise already operating in Korea under other names and may encourage more innovative solutions to social problems due to the loosening of top-down controls. Secondly, in both countries, while it is currently unlikely that governments will emphasise grant-funding and thereby increase the autonomy of social enterprises, there would be benefits in receiving input from social enterprises in the design of the employment and welfare services which they provide. In particular, greater acknowledgement from public organisations of the costs of service delivery, and the impact of government criteria and targets 
on quality would represent a good starting point to enable social enterprises to achieve their social goals.

\section{References}

Aiken, M. (2006). Towards market or state? Tensions and opportunities in the evolutionary path of three types of UK social enterprise. In M. Nyssens (Ed.), Social enterprise: At the crossroads of market, public polices and civil (pp. 259-271). London, Routledge.

Aiken, M., \& Bode, I. (2009). Killing the golden goose? Third sector organizations and back-towork programmes in Germany and the UK. Social Policy and Administration, 43(4), 209-225.

Aiken, M., \& Slater. R. (2007, July). Feeling the squeeze? Tabbies or tigers: The case of social enterprises contracting in the fields of recycling and work integration. Paper presented at the Fourth Annual Social Enterprise Research Conference, London.

Alcock, P. (2010). A strategic unity: Defining the third sector in the UK. Voluntary Sector Review, 1(1), 5-24.

An, P.-M., Halligan, J., \& Wilks, S. (2002). Introduction. In P-M. An, J. Halligan \& S. Wilks (Eds.), Reforming public and corporate governance: Management and the market in Australia, Britain and Korea (pp.1-18). Cheltenham, Edward Elgar.

Bland, J. (2010). Social enterprise solutions for 21 st Century challenges: The UK model of social enterprise and experience (Strategic Projects 25/2010). Helsinki: Ministry of Employment and the Economy,.

Carmel, E., \& Harlock, J. (2008). Instituting the 'third sector' as a governable terrain: Partnership, procurement and performance in the UK. Policy \& Politics, 36(2), 155-71.

Chikoto, G. L. (2007). Government funding and INGOs' autonomy: A tool choice approach (Working Paper 07-06). Atlanta, GA: Andrew Young School of Policy Studies, Georgia State University.

Defourny, J. (2001). Introduction. In C. Borzaga \& J. Defourny (Eds.), The emergence of social enterprise (pp.1-28). London, Routledge.

Department of Health. (2006). Our health, our care, our say: A new direction for community services. London: Stationery Office. 
Department of Trade and Industry (DTI). (2002). Strategy for social enterprise. London: The Stationery Office.

Dunn, A., \& Riley, C. A. (2004). Supporting the not-for-profit Sector: The government's review of charitable and social enterprise. The Modern Law Review Limited, 67(4), 632-657.

Grant, S., \& Dart, R. (2008, July). The social construction of social enterprise. Paper presented at the Eighth International Society for Third Sector Research International Conference, Barcelona.

Hampson, G. (2009, July). Complex calculations reveal 62,000 UK social enterprises. Social Enterprise Magazine. Retrieved from http://www.socialenterpriselive.com/section/news/policy/20090728/complex-calculationsreveal-62000-uk-social-enterprises

Haugh, H., \& Kitson, M. (2007). The third way and the third sector: New Labour's economic policy and the social economy. Cambridge Journal of Economics, 31(6), 973-994.

Hewitt, P. (2001, July 5). Hearing other voices. The Guardian. Retrieved from http://www.guardian.co.uk/politics/2001/jul/05/labour.uk1/print

HM Treasury. (1999). Enterprise and social exclusion: National strategy for neighbourhood renewal. London: The Stationery Office.

Hwang, G.-J. (2006) Pathways to state welfare in Korea: Interests, ideas, and institutions, Aldershot: Ashgate.

Ingram, H. \& Schneider, A. (1993). Constructing citizenship: The subtle messages of policy design. In H. Ingram \& S.R. Smith (Eds.), Public policy for democracy (pp. 68-98). Washington, DC: Brookings.

Ingram, H., Schneider, A. L., \& deLeon, P. (2007). Social construction and policy design. In P. A. Sabatier (Ed.), Theories of the policy process (pp. 93-126). Boulder, CO: Westview Press. Joongang Sunday. (2008, October 5). Variety of donations within the maximum profits such as 'Paul Newman-type' and 'Google-type': The cases of the US and the UK where social enterprise is popular'. Joongang Sunday. Retrieved from http://sunday.joins.com/article/view.asp?aid=9235 (in Korean).

Kendall, J. (2000). The mainstreaming of the third sector into public policy in England in the late 1990s: Whys and wherefores (Civil Society Working Paper 2). London: LSE. 
Kerlin, J. (2010, July). Historical institutionalism and social enterprise development: Towards a comparative framework for social enterprise. Paper presented at the International Society for Third Sector Research Conference, Istanbul.

Kim, H. W. (2008). The formation of social enterprise policy and prospects for social enterprise in Korea. Journal of Korean Social Trends and Perspectives, 75, 74-108 (in Korean).

Kim, J. K. (2009). The future of social enterprise. Seoul: Korean Institute for Future Strategies (in Korean).

Kim, S. K. (2009). An exploratory study of the characteristics of social enterprise in Korea: Issues and implications. Social Welfare Policy, 36(2), 139-166 (in Korean).

Kim, J. W. (2009). What is social enterprise? Seoul: Arche (in Korean).

Kim, Y. H. (2010). Is social enterprise policy redistributive or distributive? A classification and comparison of Korean social enterprises. Korean Policy Studies Review, 19(4), 211-248 (in Korean).

Kingdon, J. W. (1995). Agendas, alternatives, and public policies (2nd ed.). New York: Longman.

Ko, H. M. (2007, December). Social enterprise policy and prospects for social enterprise in Korea. Paper presented at the Korean Sociology Association Conference, Seoul (in Korean).

Kwak, S. H. (2010. 12.15). A three year performance analysis of social enterprise. Seoul: ML (in Korean).

Labour Party. (1996). New Labour new Britain: Policy handbook. London: Labour Party.

Lyons, M. (2002, November). Institutional prerequisites for successful compacts between governments and the third sector, or why a compact is not yet possible in Australia. Paper presented at the Sixth Australia New Zealand Third Sector Research Conference, Auckland.

Mawson, J. (2010). Social enterprise, strategic networks and regional development: The West Midlands experience. International Journal of Sociology and Social Policy, 30(1/2), 66-83.

Marks, L., \& Hunter, D. J. (2007). Social enterprises and the NHS: Changing patterns of ownership and accountability. London: Unison.

McCabe, A., \& Hahn, S. (2006). Promoting social enterprise in Korea and the UK: Community economic development, alternative welfare provision or a means to welfare to work? Social Policy and Society, 5(3), 387-398. 
Ministry of Labour (ML). (2009). Social enterprise performance analysis 2008. Seoul: ML (in Korean).

Mintrom, M., \& Norman, P. (2009). Policy entrepreneurship and policy change. The Policy Studies Journal, 37(4), 649-667.

Nicholls, A. (2009). Institutionalizing social entrepreneurship in regulatory space: Reporting and disclosure by community interest companies. Accounting, Organizations and Society, 35(4), 394-415.

Nicholson-Crotty, S., \& Meier, K. J. (2005). From perception to public policy: Translating social constructions into policy designs. In A. L. Schneider \& H. Ingram (Eds.), Deserving and entitled: Social construction and public policy (pp.223-242). Albany, NY: SUNY Press.

Nyssens, M. (2009). Western Europe. In J.A. Kerlin (Ed.), Social enterprise: A global comparison (pp. 12-34). Lebanon, NH: Tuft University Press.

Office of the President. (2008). One hundred policy tasks of the Lee Myung-Bak Administration. Retrieved from http://english.president.go.kr/government/goals/goals.php (in Korean).

Park, C.-U. (2008, November). The institutional embeddedness of social enterprise in welfare state regime: The case of Korea. Paper presented at the Fifth East Asian Social Policy Conference, Taipei.

Park, C.-U. (2009, July). The Korean model of social enterprises? A comparison with European experiences. Paper presented at the Social Policy Association Conference, Edinburgh.

Parkinson, C., \& Howorth, C. (2008). The language of social entrepreneurs. Entrepreneurship and Regional Development, 20(3), 285-309.

Peng, I. (2009). The Political and social economy of care in the Republic of Korea (Gender and Development Programme Paper Number 6). Geneva: UNRISD.

Pharoah, C., Scott, D., \& Fisher, A. (2004). Social enterprise in the balance: Challenges for the voluntary sector. West Malling: Charities Aid Foundation.

Ridley-Duff, R. (2007). Communitarian perspectives on social enterprise. Corporate Governance: An International Review, 15, 382-392.

Sabatier, P. A., \& Weible, C. M. (2007). The advocacy coalition framework: Innovation and clarification. In P. A. Sabatier (Ed.), Theories of the policy process (2nd ed.) (pp. 189-220). Boulder, CO: Westview Press. 
Schneider, A. L., \& Ingram, H. (1993). Social construction of target populations: Implications for politics and policy. American Political Science Review, 87(2), 334-347.

Schneider, A. L., \& Ingram, H. (1997). Policy design for democracy. Lawrence, KS: University Press of Kansas.

Schneider, A. L., \& Ingram, H. (2005). Introduction: Public policy and the social construction of deservedness. In A. L. Schneider \& H. Ingram (Eds.), Deserving and entitled: Social construction and public policy (pp. 1-28). Albany, NY: SUNY Press.

Schneider, A. L., \& Sidney, M. (2009). What is next for policy design and social construction theory? The Policy Studies Journal, 37(1), 103-119.

Scourfield, P. (2007) Social care and the modern citizen: Client, consumer, service user, manager and entrepreneur. British Journal of Social Work, 37, 107-22.

Simon, H. (1997). Administrative behaviour: A study of decision-making processes in administrative organization (4th ed.). New York: Free Press.

Smith, J. (2000, May 24). At the heart of the action. The Guardian. Retrieved from http://www.guardian.co.uk/society/2000/may/24/guardiansocietysupplement7?INTCMP=SRC $\mathrm{H}$

Social Enterprise London. (2000). Social enterprise in a regional context. Retrieved from www.sel.org.uk

Social Enterprise Promotion Agency. (2010). Social enterprise directory 501. Seoul: Social Enterprise Promotion Agency (in Korean).

Teasdale, S. (2011). What's in a name? Making sense of social enterprise discourses. Public Policy and Administration. Retrieved from doi: 10.1177/0952076711401466

Teasdale, S., Alcock, P., \& Smith, G. (2012). Legislating for the big society? The case of the Public Services (Social Enterprise and Social Value) Bill. Public Money \& Management, 32 (3), 201-208.

Wildavsky, A. (1979). Speaking truth to power: The art and craft of policy analysis. Boston, MA: Little, Brown \& Co.

Wolch, J. R. (1990). The shadow state: Government and voluntary sector in transition. New York: Foundation Centre.

Yin, R. K. (2002). Case study research: Design and methods (3rd ed.). Thousand Oaks, CA: Sage. 
Figure 1. Policy design and the social construction of social enterprise.

\begin{tabular}{|c|c|c|c|c|}
\hline \multicolumn{2}{|c|}{ Contextual relations } & UK & Comparison & Korea \\
\hline \multirow[t]{2}{*}{$\begin{array}{l}\text { Indirect } \\
\text { factors }\end{array}$} & $\begin{array}{l}\text { Economic } \\
\text { environment }\end{array}$ & $\begin{array}{l}\text { Relative economic stability until } \\
2008 \text { financial crisis } \\
\text { Reduction of direct state } \\
\text { provision of welfare }\end{array}$ & 1 & $\begin{array}{l}\text { Asian financial crisis, jobless } \\
\text { growth and } 2008 \text { financial crisis } \\
\text { Increasing state role in the } \\
\text { regulation of welfare }\end{array}$ \\
\hline & $\begin{array}{l}\text { Political orientation } \\
\text { of government }\end{array}$ & $\begin{array}{l}\text { Period 1-3: Centre-left (Third } \\
\text { way) (Blair/Brown) }\end{array}$ & $\fallingdotseq$ & $\begin{array}{l}\text { Period 1-2: Centre-left (Kim \& } \\
\text { Roh) Period 3: Conservative (Lee) }\end{array}$ \\
\hline \multicolumn{2}{|c|}{ Problem identified } & $\begin{array}{l}\text { Social exclusion/Social service } \\
\text { provision }\end{array}$ & $\neq$ & Financial crisis/Job creation \\
\hline \multirow[t]{2}{*}{$\begin{array}{l}\text { Direct } \\
\text { factors }\end{array}$} & Public policy & $\begin{array}{l}\text { Significant impact of public } \\
\text { policy on the social construction } \\
\text { of social enterprise }\end{array}$ & 1 & $\begin{array}{l}\text { Significant impact of public } \\
\text { policy on the social construction } \\
\text { of social enterprise }\end{array}$ \\
\hline & Policy entrepreneur & $\begin{array}{l}\text { Policy entrepreneurs in } \\
\text { government and among social } \\
\text { enterprise practitioners }\end{array}$ & $\neq$ & $\begin{array}{l}\text { No conspicuous policy } \\
\text { entrepreneur }\end{array}$ \\
\hline \multirow[t]{3}{*}{$\begin{array}{l}\text { Design } \\
\text { inten- } \\
\text { tion }\end{array}$} & $\begin{array}{l}\text { Usage of social } \\
\text { enterprise/ degree of } \\
\text { control }\end{array}$ & $\begin{array}{l}\text { Instrumental rationality } \\
\text { (contracting out)/mid }\end{array}$ & $\fallingdotseq$ & $\begin{array}{l}\text { Instrumental rationality } \\
\text { (approval system)/very high }\end{array}$ \\
\hline & $\begin{array}{l}\text { Effects of policy } \\
\text { implementation }\end{array}$ & $\begin{array}{l}\text { Reinforcement of market- } \\
\text { oriented approach }\end{array}$ & $\fallingdotseq$ & $\begin{array}{l}\text { Reinforcement of market- } \\
\text { oriented approach }\end{array}$ \\
\hline & & $\begin{array}{l}\text { High degree of dependence on } \\
\text { government contracts }\end{array}$ & $\neq$ & Government as gatekeeper \\
\hline
\end{tabular}


Table 1. Social enterprise policy in the UK over three periods.

\begin{tabular}{|l|l|l|l|}
\hline Timeline & $\begin{array}{l}\text { 1997-2000: Period 1 } \\
\text { First Blair government }\end{array}$ & $\begin{array}{l}\text { 2001-2005: Period 2 } \\
\text { Second Blair government }\end{array}$ & $\begin{array}{l}\text { 2005-2010: period 3 } \\
\text { Blair/Brown }\end{array}$ \\
\hline Public policy & The Third Way & $\begin{array}{l}\text { Strategy for Social Enterprise } \\
\text { CIC legislation }\end{array}$ & $\begin{array}{l}\text { Our health, our care, our say } \\
\text { (Department of Health, } \\
\text { 2006). }\end{array}$ \\
\hline $\begin{array}{l}\text { Main } \\
\text { governmental } \\
\text { department }\end{array}$ & Treasury & $\begin{array}{l}\text { Department of Trade \& } \\
\text { Industry }\end{array}$ & Office of the Third Sector \\
\hline $\begin{array}{l}\text { Main policy } \\
\text { partners/ policy } \\
\text { tool }\end{array}$ & $\begin{array}{l}\text { Cooperatives \& voluntary } \\
\text { sector organisations/ } \\
\text { Community development \& } \\
\text { contracting-out }\end{array}$ & $\begin{array}{l}\text { Voluntary sector organisations } \\
\text { \& social businesses/ } \\
\text { Contracting out }\end{array}$ & $\begin{array}{l}\text { Earned income for non- } \\
\text { profits }\end{array}$ \\
\hline $\begin{array}{l}\text { Target } \\
\text { beneficiaries }\end{array}$ & $\begin{array}{l}\text { Housing, social care, leisure } \\
\text { centres, communities, work } \\
\text { integration }\end{array}$ & Third sector as a whole & $\begin{array}{l}\text { Third sector as a whole \& } \\
\text { NHS }\end{array}$ \\
\hline Policy field & Business/voluntary sector & Business/voluntary sector & Voluntary sector/ NHS \\
\hline Target problem & $\begin{array}{l}\text { Social exclusion/service } \\
\text { provision }\end{array}$ & Service provision & $\begin{array}{l}\text { Service provision/ NHS } \\
\text { inefficiency }\end{array}$ \\
\hline
\end{tabular}

Table 2. Social enterprise policy in Korea over three periods.

\begin{tabular}{|l|l|l|l|}
\hline Timeline & $\begin{array}{l}\text { 1999-2002: Period 1 } \\
\text { Kim administration }\end{array}$ & $\begin{array}{l}\text { 2003-2007: Period 2 } \\
\text { Roh administration }\end{array}$ & $\begin{array}{l}\text { 2007-2010: period 3 } \\
\text { Roh/Lee administration }\end{array}$ \\
\hline Public policy & $\begin{array}{l}\text { Public Work Programme } \\
\text { (National Basic Livelihood } \\
\text { Security Act) }\end{array}$ & Social Workplace Program & $\begin{array}{l}\text { Social Enterprise Policy } \\
\text { (Social Enterprise Promotion } \\
\text { Act) }\end{array}$ \\
\hline $\begin{array}{l}\text { Main governmental } \\
\text { department }\end{array}$ & $\begin{array}{l}\text { MHW as lead department } \\
\text { (\& ML as partner) }\end{array}$ & $\begin{array}{l}\text { ML as lead department (\& } \\
\text { other departments including } \\
\text { MHW as partners) }\end{array}$ & ML \\
\hline $\begin{array}{l}\text { Main policy } \\
\text { partners/ policy tool }\end{array}$ & $\begin{array}{l}\text { SSCC (cooperatives)/ } \\
\text { Contracting out }\end{array}$ & $\begin{array}{l}\text { US-style NPO \& SSCC/ } \\
\text { Contracting out }\end{array}$ & $\begin{array}{l}\text { Social enterprise/ approval } \\
\text { system }\end{array}$ \\
\hline Target beneficiaries & $\begin{array}{l}\text { Welfare recipients and/or } \\
\text { the near poor }\end{array}$ & $\begin{array}{l}\text { Expansion to general unemployed (those ineligible for basic } \\
\text { welfare) }\end{array}$ \\
\hline Policy field & $\begin{array}{l}\text { Combination of welfare } \\
\text { and labour policy }\end{array}$ & Labour policy (welfare policy became secondary) \\
\hline Target problem & $\begin{array}{l}\text { Poverty and unemployment } \\
\text { (due to Asian financial } \\
\text { crisis) }\end{array}$ & Jobless growth & $\begin{array}{l}\text { Unemployment (exacerbated } \\
\text { by financial crisis) }\end{array}$ \\
\hline
\end{tabular}


Table 3. Approved social enterprises in Korea by goal type (December 2010).

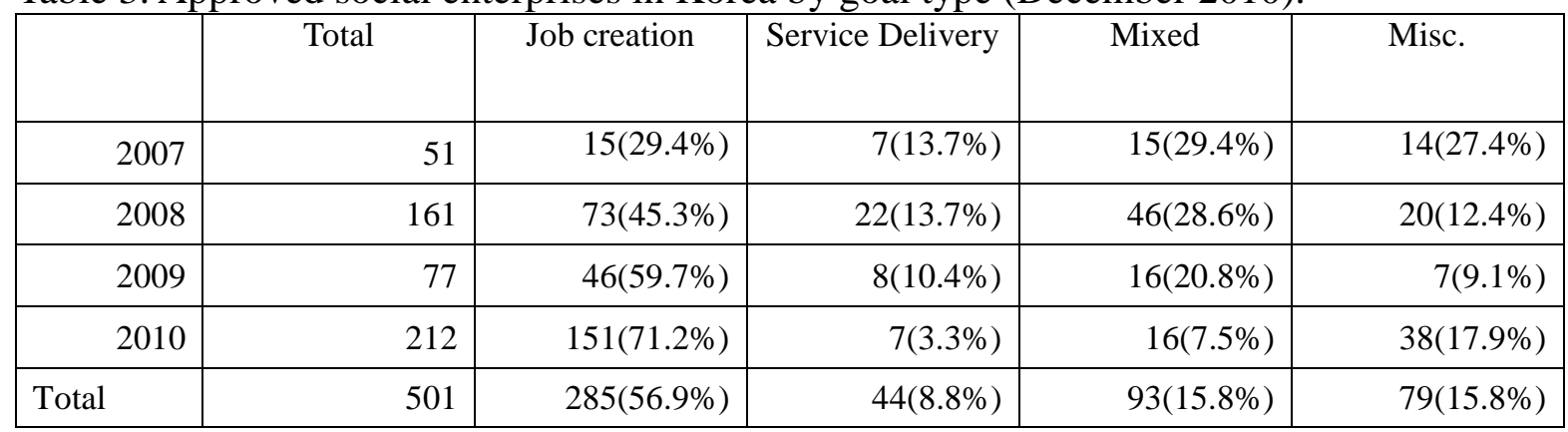

Source: Kwak (2010, p. 29) and Social Enterprise Promotion Agency (2010, p. 16).

Table 4. Approved social enterprises in Korea by organisational type (December 2010).

\begin{tabular}{|r|r|r|r|r|r|r|r|}
\hline & \multicolumn{1}{|l|}{ Total } & Business & Nonprofit & $\begin{array}{l}\text { Social } \\
\text { welfare } \\
\text { foundations }\end{array}$ & SSCC & $\begin{array}{l}\text { Inc. } \\
\text { Association }\end{array}$ & $\begin{array}{l}\text { Educational } \\
\text { foundation }\end{array}$ \\
\hline 2007 & 51 & $21(41.2 \%)$ & $4(7.8 \%)$ & $5(9.8 \%)$ & $5(9.8 \%)$ & $16(31.4 \%)$ & $0(0.0 \%)$ \\
\hline 2008 & 161 & $70(43.5 \%)$ & $21(13.0 \%)$ & $27(16.8 \%)$ & $6(3.7 \%)$ & $37(23.0 \%)$ & $0(0.0 \%)$ \\
\hline 2009 & 77 & $35(45.5 \%)$ & $13(16.9 \%)$ & $9(11.7 \%)$ & $0(0.0 \%)$ & $20(26.0 \%)$ & $0(0.0 \%)$ \\
\hline 2010 & 212 & $83(39.2 \%)$ & $51(24.1 \%)$ & $18(8.5 \%)$ & $2(0.9 \%)$ & $57(26.9 \%)$ & $1(0.5 \%)$ \\
\hline Total & 501 & $209(41.7 \%)$ & $89(17.8 \%)$ & $59(11.8 \%)$ & $13(2.6 \%)$ & $130(25.9 \%)$ & $1(0.2 \%)$ \\
\hline
\end{tabular}

Source: Kwak (2010, p. 29) and Social Enterprise Promotion Agency (2010, p. 15). 